\title{
Online Learning is a Way Forward During Pandemic
}

\author{
Syeda Rida Baqir, Abida Arif
}

How to cite this Article:

Baqir SR, Arif A. Online Learning is a Way Forward During Pandemic.J Bahria Uni Med Dental Coll. 2021; 11(1):46 DOI: https://doi.org/ 10.51985/QEQU9569

This is an Open Access article distributed under the terms of the Creative Commons Attriution Non Commercial Liciense (http:// creativecommons/org/licences/by-nc/4.0) which permits unrestricted non commercial use, distribution and reproduction in any medium, provided the original work is properly cited.

COVID-19 or corona virus is a natural disaster which is provoking panic throughout the world. Against this new pandemic virus, no vaccine is available. Many countries are affected by this Pakistan a large number of cases observed throughout Pakistan were recorded. ${ }^{1}$ Due to the COVID19 , colleges and universities is seriously affected since March 2020. Constraint recommended by the government and other organizations to address the educational process by strictly following protective measures against coronavirus for teachers, and learners. Several institutes have stopped all physical classes in universities and schools, including practical sessions. The educational process is facilitated through online in account of safety measures against coronavirus. $^{2}$

Globally, many teachers and students show enthusiasm towards the delivery of education through online mode. Teachers have already making plans that how to provide effective online lessons to their students. ${ }^{3}$

There are many degrees awarding institutes which are authorized by Higher Education Commission (HEC) in Pakistan. ${ }^{4}$ Online education, examinations and assessments are started by University of health Sciences (UHS), during this pandemic COVID - 19 .

Online education is also called electronic learning it is the interaction between educators and learners through internet service desktop, laptop or mobile. It comprises of multiple formats like video, audio, documents etc. Following are the online modalities through which online quality education can be maintained.

1) Online lectures which can be given through different applications like zoom, Microsoft teams, google classroom, hang out etc

2) Online tutorials (asynchronous) it comprises of online multimedia learning tutorials in which video, animations,

\begin{tabular}{|c|}
\hline $\begin{array}{l}\text { Syeda Rida Baqir } \\
\text { Senior Lecturer } \\
\text { Bahria University College of Physical Therapy } \\
\text { Bahria University Medical \& Dental College }\end{array}$ \\
\hline $\begin{array}{l}\text { Abida Arif } \\
\text { Senior Lecturer, } \\
\text { Bahria University College of Physical Therapy } \\
\text { Bahria University Medical \& Dental College }\end{array}$ \\
\hline $\begin{array}{l}\text { Received: 21-Jul-2020 } \\
\text { Accepted: 11-Nov-2020 }\end{array}$ \\
\hline
\end{tabular}

assignments and quizzes are used at the available resources for this purpose are: Aquifer, FOAMed, MedEdPortal, the New England Journal of Medicine video series or OpenPediatrics. ${ }^{5}$

3) Online videos is commonly available platform, through which practical skills can be studied or synchronous online video.

4) Tele school is the channel which is launched by education ministry of Pakistan in corona virus season of lockdown through PTV (Pakistan television). This channel work for the promotion of education in Pakistan. The Education Minister of Pakistan 2020 said that the channel will be accessible from $8 \mathrm{am}$ to $6 \mathrm{pm}$ for class 1 to class 12 . The Prime Minister of Pakistan 2020 has given the suggestion that this channel ought to carry on afterward the ended. The Prime Minister said it will be beneficial for the promotion of education in distant zones of our country while the - - - - - - - - - - - - - - I Authors Contribution:

I Syeda Rida Baqir: Final editing

I Abida Arif: Final proof reading

I ---------------1

\section{REFERENCES:}

1. Ncoc.gov.pk. See the Realtime Pakistan and Worldwide COVID-19 situation. (2020). Available from https:// www. covid.govt.pk/coronavirus

2. Farooq F, Rathore FA, Mansoor SN. Challenges of Online Medical Education in Pakistan During COVID-19 Pandemic. J Coll Phys Surg Pak. 2020;30(1):67-9.

3. Sahu P. Clouser of universities due to corona virus disease 2019 (COVID-19): Impact on Education and Mental Health of students and academic staff. Cureus. 2019; 12 (4): e7541. 1-6

4. Akram J, Meo SA. Pakistan role in COVID-19 pandemic. Biomedica. 2020; 36:1-4.

5. Singh K, Srivastav S, Bhardwaj A, Dixit A, Misra S. Medical education during the COVID-19 pandemic: a single institution experience. Ind Ped. 2020;57(7):678-9. 